\title{
EVALUASI KETERAMPILAN MEMBERI PENGUATAN OLEH MAHASISWA PGSD SEMESTER VI MATA KULIAH PEMBELAJARAN MIKRO PADA MATERI TEMA 6 KELAS 5 SD
}

\section{INFO ARTIKEL}

Riwayat Artikel:

Diterima:25-Juni-2021

Disetujui:28-September-2021

\section{Kata Kunci:}

Keterampilan Mengajar

Keterampilan Penguatan

Pembelajaran Mikro

\author{
Nimas Windyantika ${ }^{1}$, Nur Ngazizah ${ }^{2}$ \\ 12 Pendidikan Guru Sekolah Dasar, Universitas Muhammadiyah Purworejo \\ nimaswindyantika@gmail.com
}


guru siswa harus memiliki keterampilan dasar mengajar. Keterampilan mengajar dasar dapat dilatih melalui pembelajaran mikro.

Pembelajaran mikro memiliki tujuan untuk membantu mengembangkan keterampilan mengajar sehingga dapat dijadikan sebagai bekal mengajar di sekolah atau di lapangan. Pengalaman pembelajaran mikro dapat memberikan manfaat seperti memperlihatkan calon guru dalam mengajar sebenarnya, membantu calon guru melihat pentingnya pelaksanaan, pengambilan keputusan, pelaksanaan instruksi, memungkinkan calon guru mengembangkan dan meningkatkan keterampilan mereka dan membantu calon guru dalam membangun kepercayaan diri dalam mengajar.

Pada kurikulum PGSD Universitas Muhammadiyah Purworejo, pelaksanaan pembelajaran mikro diberikan pada semester VI karena mahasiswa akan melaksanakan Magang 3 dan yaitu mengajar di kelas secara langsung. Sehingga dengan adanya pembelajaran mikro diharapkan mahasiswa siap dalam melaksanakan magang 3 ataupun praktik di lapangan. Salah satu kompetensi yang dituntut dari kompetensi mengajar adalah kemampuan melaksanakan pembelajaran yang mendidik. Dengan pemahaman dan kemampuan menerapkan keterampilan dasar mengajar secara utuh dan terintegrasi, guru atau calon guru diharapkan mampu meningkatkan kualitas proses pembelajaran

Keterampilan dasar mengajar merupakan kemampuan atau keterampilan yang bersifat khusus yang harus dimiliki guru agar dapat melaksanakan tugasnya secara efektif, efisien, dan professional (As. Gilcman pada prosiding roro diah UMJ, 2018). Keterampilan memberi penguatan merupakan salah satu keterampilan dasar mengajar yang sangat penting untuk dikuasai oleh guru dan calon guru. Penguatan merupakan respon terhadap suatu tingkah laku atau tindakan yang dapat meningkatkan kemungkinan berulangnya kembali tingkah laku atau tindakan tersebut. Penguatan bertujuan untuk memberikan informasi atau umpan balik bagi siswa atas perbuatannya sebagai suat tindakan mendorong atau mengkoreksi (Nurdin, 2016). Tetapi, seringkali pemberian penguatan oleh guru jarang dilakukan yang diasumsikan berdampak pada kurang optimalnya hasil belajar siswa.

Kegiatan simulasi atau evaluasi mengajar mahasiswa PGSD UMP (Universitas Muhammadiyah Purworejo) dengan pemberian teori keterampilan dasar mengajar terlebih dahulu kemudian dilanjutkan dengan perancangan RPP (Rencana Pelaksanaan Pembelajaran). Untuk mengetahui bagaimana keterampilan dasar mengajar terhadap calon guru, peneliti melakukan observasi terhadap mahasiswa PGSD kelas B semester 6 pada mata kuliah pembelajaran mikro tahun akademik 2020/2021. Dengan tujuan penelitian yaitu mengidentifikasi kemampuan keterampilan memberi penguatan mahasiswa semester 6 sebagai calon pendidik atau guru.

\section{B. METODE PENELITIAN}

Metode yang digunakan dalam penelitian ini adalah metode penelitian kuantitatif dengan pendekatan ex post facto. Pendekatan tersebut mengungkapkan fakta yang telah terjadi tanpa adanya manupulasi variable atau menciptakan kondisi tertentu. Penelitian dilakukan terhadap mahasiswa semester 6 PGSD Universitas Muhammadiyah Purworejo tahun akademik 2020/2021 kelas B pada mata kuliah pembelajaran mikro yaitu sebanyak 14 orang $(n=14)$. Waktu pelaksanaan penelitian mulai bulan Maret 2021 sampai bulan April 2021.

Angket penilaian merujuk pada indikator keterampilan dasar mengajar yaitu keterampilan memberi penguatan sebagai data primer dan evaluasi diri melalui observasi penelitian. Pengumpulan data dilakukan pada saat praktikan melakukan praktik mengajar di kelas mikro. Dengan cara memberikan centang "ya" atau "tidak" pada indikator yang tercapai pada angket penelitian yang telah disediakan. Angket diisi oleh mahasiswa yang tidak melaksanakan praktik mengajar, kemudian setelah praktik dilakukan evaluasi agar diketahui keterampilan yang dimiliki dengan kemampuan yang perlu dikembangkan lagi.

\section{HASIL DAN PEMBAHASAN HASIL PENELITIAN}

Berdasarkan hasil penelitian pada angket penilaian pelaksanaan kegiatan pembelajaran mikro hasil yang diperoleh untuk mengetahui kemampuan dasar keterampilan memberikan penguatan mahasiswa PGSD semester 6 sebanyak 14 mahasiswa sebagaimana dalam diagram berikut ini. 


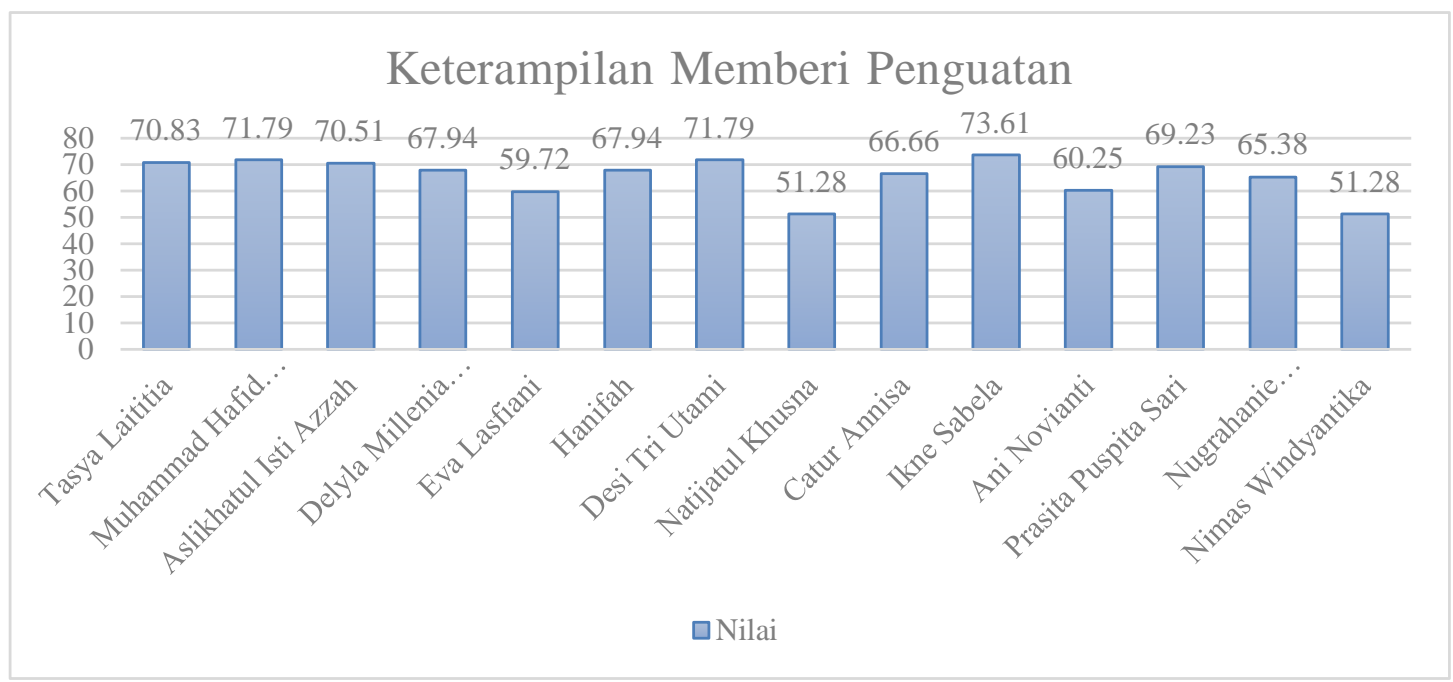

Gambar 1. Nilai Keterampilan Memberi Penguatan setiap Mahasiswa

Kategori nilai dapat dikonversikan sebagai berikut:

$\mathrm{A}=$ Sangat baik dengan nilai $76-100$

$\mathrm{B}=$ Baik dengan nilai 51-75

$\mathrm{C}=$ Cukup dengan nilai 26-50

$\mathrm{D}=$ Kurang dengan nilai $0-25$

Berdasarkan gambar $1 \mathrm{di}$ atas tingkat penguasaan keterampilan memberi penguatan mahasiswa PGSD semester 6 memperoleh hasil B dengan kategori baik. Perolehan nilai mahasiswa pada keterampilan memberi penguatan dari nilai tertinggi ke rendah adalah sebagai berikut : (1) Ikne Sabela dengan nilai 73,62, (2) Muhammad Hafid Musofa dengan nilai 71,79 (3) Desi Tri Utami dengan nilai 71,79 (4) Tasya Laititia dengan nilai 70,83 (5) Aslikhatul Isti Azzah dengan nilai 70,51 (6) Prasita Puspita Sari dengan nilai 69,23 (7) Hanifah dengan nilai 67,94 (8) Delyla Milenia Valent dengan nilai 67,94 (9) Catur Annisa dengan nilai 66,66 (10) Nugrahanie Candra Maulidya dengan nilai 65,38 (11) Ani Novianti dengan nilai 60,25 (12) Eva Lasfiani dengan nilai 59,72 (13) Nimas Windyantika dengan nilai 51,28 (14) Natijathul Khusna dengan nilai 51,28.

\section{PEMBAHASAN}

Berdasarkan observasi penilaian simulasi keterampilan dasar mengajar pada keterampilan memberi penguatan. Mahasiswa PGSD semester 6 kelas B termasuk dalam kategori baik dengan nilai rata-rata keterampilan dasar mengajar yaitu 65,58. Nilai tertinggi diperoleh Ikne Sabela dengan nilai 73,63 dan nilai terrendah dengan nilai 51,28 diperoleh dua mahasiswa yaitu Nimas Windyantika dan Natijathul Khusna. Perlu adanya evaluasi diri dari saran dan kritik yang diberikan oleh mahasiswa lain pada saat refleksi setelah melakukan simulasi keterampilan pembelajaran.

Kegiatan belajar mengajar akan berlangsung dengan baik dan sukses jika pendidik mengajarkan mata pelajaran yang sudah di pahami dan dengan keterampilan dasar mengajar yang harus dikuasai yaitu dapat membuka pembelajaran dengan baik serta menggunakan media pembelajaran yang tepat, dapat merespon dengan positif tingkah laku peserta didik dan dapat memberikan stimulus serta memberikan penjelasan dalam meningkatkan penalaran peserta didik (Nurdin, 2016). Kemampuan keterampilan mengajar membekali guru dalam melaksanakan tugas dan tanggung jawab sebagai pengajar, keterampilan mengajar merupakan tujuan untuk mencapai keberhasilan pengajaran (Roro Diah, 2018).

Diantara delapan keterampilan yang ada pada penelitian ini lebih memusatkan pada keterampilan memberi penguatan, karena keterampilan memberi penguatan seringkali terlupakan oleh pengajar atau guru sehingga kurang memberikan stimulus pada peserta didik. Keterampilan memberi penguatan merupakan respon dari tingkah laku positif yang dapat meningkatkan kemungkinan berulang tingkah laku tersebut. Tindakan tersebut dimaksudkan untuk membesarkan hati siswa agar mereka lebih giat berpartisipasi dan berinteraksi dalam proses pembelajaran (Mansyur, 2017).

Keterampilan memberikan penguatan terdiri dari beberapa komponen yang perlu dippahami dan dikuasai agar dapat memberikan penguatan secara bijaksana dan sistematis. Komponen-komponen tersebut antara lain : (1) Penguatan verbal yaitu penguatan yang diungkapkan dengan menggunakan kata-kata pujian, penghargaan, persetujuan, dan sebagainya. (2) Penguatan non verbal yaitu penguatan dengan mimik dan gerakan badan seperti 
mendekati, memberikan sentuhan, penguatan dengan kegiatan yang menyenangkan, penguatan menggunakan simbol atau benda dan penguatan tak penuh. Penggunaan penguatan secara efektif harus memperhatikan tiga hal, yaitu kehangatan, kebermaknaan, dan menghindari penggunaan respon negative (Roro diah, 2018).

\section{SIMPULAN DAN SARAN}

Keterampilan dasar mengajar merupakan keterampilan yang kompleks, yang pada dasarnya merupakan pengintegrasian utuh dari berbagai keterangan yang sangat banyak. Keterampilan dasar mengajar terdiri dari delapan jenis ketermpilan, yaitu keterampilan membuka dan menutup pembelajaran, keterampilan mengadakan variasi, keterampilan mengelola kelas, ketermpilan memberi penguatan, keterampilan membimbing diskusi kelompok kecil, keterampilan mmengajar kelompok kecil dan perorangan, keterampilan bertanya, dan keterampilan menjelaskan. Pada penelitian di lebih memfokuskan pada keterampilan penguatan, keterampilan penguatan merupakan respon positif tehadap tingkah laku atau tindakan dari peserta disik dengan dua komponen yaitu penguatan verbal (memberikan pujian) dan penguatan non-verbal (sentuhan, tepuk tangan, simbol, dll). Berdasarkan hasil penilaian melalui angket yang telah disediakan mahasiswa PGSD semester 6 kelas B memperoleh nilai rata-rata pada keterampilan memberi penguatan yaitu 65,58 dengan kategori Baik. Pada keterampilan memberi penguatan ini mahasiswa masih perlu meningkatkan kemampuannya agar menjadi lebih baik lagi.

\section{DAFTAR RUJUKAN}

[1] Asran, M. Penerapan Keterampilan Memberikan Penguatan terhadap Hasil Belajar Siswa dalam Pembelajaran Pendidikan Kewarganegaraan Kelas IV. Jurnal Pendidikan dan Pembelajaran Khatulistiwa, 4(6).

[2] Mansur, N. 2017. Penerapan Keterampilan Mengajar Dalam Upaya Pencapaian Hasil Belajar Mahasiswa. Lantanida Journal, 4(2), 118-127.

[3] Mansyur, M. 2017. Keterampilan Dasar Mengajar dan Penguasaan Kompetensi Guru (suatu Proses Pembelajaran Micro). El-Ghiroh: Jurnal Studi Keislaman, 12(1), 130-147.

[4] Ngazizah, N., Safitri, D., \& Hadi, A. S. 2019. Evaluasi keterampilan mengajar mahasiswa PGSD semester VI pada mata kuliah pembelajaran mikro tahun akademik 2018/2019. Proceeding of The URECOL, 315-320.

[5] Sundari, F. S., \& Muliyawati, Y. 2017. Analisis keterampilan dasar mengajar mahasiswa PGSD. Pedagonal: Jurnal Ilmiah Pendidikan, 1(1), 26-36.

[6] Wahyulestari, M. R. D. 2018. Ketrampilan Dasar Mengajar di Sekolah Dasar. In Prosiding Seminar Nasional Pendidikan (Vol. 1, No. 1). 